\title{
Mother Ireland and the revolutionary sisters
}

\author{
Gerry Kearns
}

Department of Geography, University of Cambridge

\begin{abstract}
The symbolic role of women in Irish nationalism has to some extent obscured their practical involvements. By studying some of the most prominent female nationalists, this paper shows how women often read representations of women as icons of nationhood very much against the grain of the passive interpretations favoured by later historians. The paper also shows how heavily contested was the ultimate exclusion of women from public and political spaces.
\end{abstract} he allegorical role of women as an image of the Irish nation is well known. Culling-
ford refers to a native tradition of representing Ireland as feminine:

Ancient sovereignty goddesses, eighteenth-century aisling poems, in which a beautiful maiden lamented her rape by the colonizer or the loss of her Irish prince, and post-Famine devotion to the Virgin fed into an over-determined tradition that, whether it valorized or despised 'feminine' qualities, regularly attributed them to the Celts. ${ }^{1}$

Whether personified as a young woman violated by the colonial English, or as a mother, wife or sister weeping over her murdered menfolk, or as an old woman, Kathleen Ní Houlihan, once comely but now awaiting her young admirers to sacrifice themselves for her and thus restore to her a youthful beauty, Ireland was ever a woman: 'Female figures play a large role in early Irish myths and sagas and are often associated with fertility and the well-being of the landscape. ${ }^{2}$ The fertility of the Irish land, of Mother Ireland, held out the promise of a bountiful future once that biology was released from colonial captivity. ${ }^{3}$ In many of these representations the female figure is passive: violated, avenged or inseminated, she rarely acts on her own behalf. Quite often, this reading of women is represented by monuments and iconography that colonize the public spaces of civil society. ${ }^{4}$ This feminizing of the nation produces, Boland has suggested, a nationalizing of women, leaving no space for considering their distinctive needs. Cullingford argues that the 'myth of the woman as pure mother demanding sacrifice of her sons' expresses purely male fears 'of the all-powerful mother of infancy' and that '[a]doration and abhorrence are fused in a symbol that ignores women's own desire. 5 Living women are considered as national resources. Only in the service of others are they allowed to realise their potential: 'Women's public role as citizens in Ireland was overshadowed by an ideological view of them as natural mothers, set apart 
from modern society, preserving the heart of some kind of persisting "organic community"., Furthermore, the circulation of allegorical women in national narratives overshadows their flesh-and-blood cousins, thus, in Boland's terms, 'evading the real women of an actual past'. ${ }^{7}$ There is, then, a neglected tradition in Irish nationalism, an underground current of female activism. Coulter believes that this tradition stands for a distinct set of values, suspicious of a central state and supportive of cooperative and local initiatives. ${ }^{8}$ The claim, then, is that the allegorical use of women as national icons elevates female passivity over activity, both in its view of the past and in its hopes for the future.

And yet this cannot be the whole story. The correspondence of image to practice is always incomplete. Yes, the rural resistance movements of eighteenth-century Ireland dressed up as women when raiding the farms of landlords, but in many cases the Whiteboys included women, dressed as men-dressed-as-women. The old woman of legend was not only stoic Kathleen but also on occasion the Shan Van Vocht who would one day return to lead her country into battle. ${ }^{9}$ The myths of the Iron Age Queen of Connacht, Maeve, represent her as sexually adventurous and ruthless. The legend of St Brigid (451 (or 452)-525) affirms that she ran her own community of nuns and advocated equality for women within the Catholic Church. More is known about Gráinne Ní Mháille (1530-1603), the pirate who captained her own ships against English merchant vessels. Allegories can serve as a guide to or justification for women's oppression only when their meaning is uncontestable. Images alone cannot do this. Images require interpretation. History and legend need their tellers. The tale is selected, told and personally accented. In many of the literary works of cultural nationalism, women were offered as capricious or passive foils to the male heroism that Yeats and others wished to revive. But these women could be, and were, read differently by some. Lady Gregory, for example, presents one mythical figure, Grania, not as capriciously marrying Finn upon the death of Diarmuid but as deliberately doing so in response to her recognition that she had only mattered to the pair of them as a symbol, a token over which they could compete, 'marrying Finn as a way to remind Diarmuid's wandering soul that she cannot be so easily dismissed. ${ }^{10}$ It required the political defeat of the women's movement to create the space where the idea of Mother Ireland could be used to discipline her revolutionary daughters. My claim, then, is that alongside the symbols and abstractions of national iconography we need to consider the political ideals and practices that animate or ridicule those images.

If we are to develop a properly contextual approach to cultural practices, then we need also to link iconography and politics to the exceptional and quotidian experiences where their inspiration or insult is fullest felt. Figure 1 represents some of these links in a simple diagram. Meaningful symbols can be understood in ways that make daily life easier or more difficult. If one's way of life is well served by the values embodied in national symbols, the daily use of those symbols reinforces the taken-forgranted social contract defining the purposes of the nation. ${ }^{11}$ If, however, one's hopes must be pursued in defiance of that social contract, the symbols may appear insulting and need rejecting. But since the meaning of symbols is often contestable, these images can sometimes be deployed in an ironic manner or their significance can be challenged. 


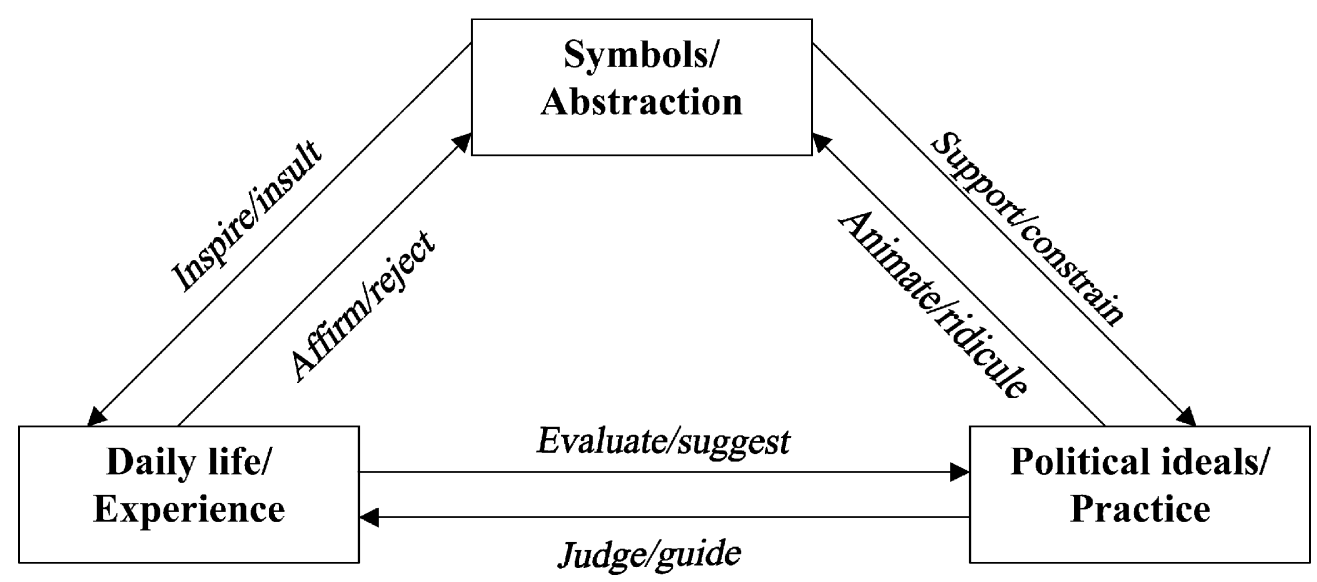

FIGURE 1 The context of symbols

A statue erected to a politician can become part of the backdrop of urban life, a reminder of the values that give meaning to this life. Yet the same statue provides an opportunity for vandalism or irreverent sayings, and the memory of repeated violations means the edifice may draw wry smiles rather than respect from passers-by. ${ }^{12}$ Experience tests symbols.

Symbols are quite often an abstraction of key principles from a life or event. They may legitimate certain political causes. Some symbols appear to censor certain causes while affirming others. St Patrick as the patron saint of Ireland appears to guarantee a Catholic reading of Irishness. The saint, however, is important within both Protestant and Catholic traditions. More disturbingly, perhaps, the strong identification of Patrick with Ireland appears to promise that his image might embrace all varieties of Irishness, and if non-Christian Irishness exists, then, the saint's image can only continue as universal if it is capable of secular uses. St Patrick's day, for example, is perhaps more a national than a religious festival, and it is this ambivalence that provides opportunities for people to use parades to contest the meaning of both Catholicism and Irishness. ${ }^{13}$ The practice of politics includes the meaningful use and abuse of symbols. The relation of politics to everyday life is mediated symbolically.

Angela Martin argues that nationalist discourses discipline real bodies. To some extent, this discipline is mediated by determining public and private spaces and denoting different behaviours and genders for each. ${ }^{14}$ Sarah Radcliffe notes that in Ecuador, gendered conceptions of home and of tradition mark out an imaginary geography of the nation organized around discourses of nostalgia, development and territory. ${ }^{15}$ In early twentieth-century Ireland there were at least two gendered discourses that wove bodies, space and gender together. In the first case, there was the attention to respectability that, as Staeheli and Thompson suggest, leads to the qualification of formal, or legal, citizenship by more substantive or moral concerns. People earn rather than inherit citizenship and thus access to the public spaces of civil society. ${ }^{16}$ The second 
theme concerns heroism. Heroism was presented by many male cultural nationalists as an exclusively male preserve. As Catherine Nash remarks, this means that nationalism defines both masculinity and femininity in relation to the powers and qualities attributed in dyadic pairs to men and women. ${ }^{17}$ Again this has a spatial dimension, with the feminine home contrasted with the hyper-masculinized public space. ${ }^{18}$ Lorraine Dowler believes that these disciplines are intensified in time of war with a pronounced 'militarised privatising of gender roles'. ${ }^{19}$ These discourses of respectability and heroism exclude women from the public spaces of civil society. However, in the case of these discourses there is many a slip twixt intention and reality. If women were denied a public voice through being understood as unrespectable, then, they could play up to this by exploiting the shock that came from their transgression of public private boundaries. In the early twentieth century, Irish women 'brought a new dimension to nationalist life, imbuing the movement with a theatrical element which stirred the imagination'. ${ }^{20}$ It is also clear that women's lack of involvement with the political process gave them the virtue of principle over pragmatism. Paradoxically, by mobilizing men for battle, war may also open a wider range of social roles for women. In times of political crisis from the 1880s onwards, the arrest and imprisonment of male activists periodically left women in charge of the nationalist movement.

These relations between bodies, space and nationalism are both contestable and ambivalent. Because gendered symbols are ambivalent, they are available both to represent patriarchal relations and as resources for people who want to challenge those relations. Symbolic representations of Ireland as woman not only promote certain visions of woman as the exemplar that living women must follow, they can also make the status of women the measure of national progress. Living women can also themselves become symbols either by embodying or challenging the exemplars. In terms of Figure 1, the gendered stereotypes would confine women to the world of experience defined by the home, leaving to men the world of practice and the public spaces of civil society. This paper first examines the contestability of these confinements by considering the careers of four remarkable women who fought for their place within those public spaces during a nationalist revolution. They did not get to live in the world of their dreams, but they inspired contemporaries who sustained feminism within the hostile world of independent Ireland. ${ }^{21}$ The way they negotiated the symbolic capital of Irish representations of the nation as woman provides resources for a continuing and critical engagement with those discourses. Turning from the experiences of these four women, I next consider how feminine symbols were used by the women themselves. Here I ask how gendered symbols proved resources for women. Finally, I turn to political practice and show the experience of these women had to be denied, and the women themselves silenced, in order to allow gendered symbols to sustain patriarchal practices.

\section{Experience: revolutionary sisters in jail}

In this paper, I want to explore some of these connections by focusing on a revolutionary period in Irish history (1890-1925) and by looking at the relations between 
feminism and nationalism, between feminists and nationalists, between women and men and also among women active in revolutionary politics. My story begins in Holloway prison, London, in August 1918. Hundreds of thousands of young people, many of them Irish, were mired in trenches in France. Under the Defence of the Realm Act, four Irish women were being held in prison for avowing that Britain and not Germany was the true enemy of the people of Ireland. They were isolated from other prisoners, sharing a landing in the wing of the prison reserved for inmates with sexually transmitted infections. The four were well known to each other and had fought several battles together in various combinations. Three of them had seen husbands murdered during the Irish rebellion of 1916. Yet the paths that had led them to Holloway were quite different and their lives could symbolize contrasting sets of values and principles. Each, however, was an activist. None of them accepted the exclusion of women from the public spaces of civil society.

\section{Feminism and peace}

Hanna Sheehy Skeffington (1877-1946) was the last to arrive at Holloway and the first to leave. ${ }^{22}$ Her father, David (1844-1932), was a member of the British parliament and a supporter of Home Rule, opposed to insurrection. His daughter believed that direct action alone could secure Irish women their freedom. Hanna had been in the United States promoting the cause of Irish independence. She had even gained an audience with President Woodrow Wilson (1856-1924) to urge the cause. On returning to Ireland she was arrested in August, kept for a time in the Dublin Bridewell before being sent across to England. This was not her first spell in prison and, as before, she went immediately on hunger strike; wary of making a martyr of her, the British released her after just three days in Holloway. Her primary political convictions were feminist, as were her husband's. When they married in 1903, Frank Skeffington (1878-1916) and Hannah Sheehy shared surnames to show they were equals. Together with another couple, James (1873-1956) and Margaret (1878-1954) Cousins, they founded in 1908 the Irish Women's Franchise League to develop in Ireland the militant tactics pioneered by the Pankhursts in England. By 1912 it had 1000 female members and 160 male associates. They also set up, in 1912, the Irish Citizen, as a suffragist newspaper.

In moving to civil disobedience the suffragettes aroused the hysterical ire of all manner of men. Their public meetings were broken up by ruffians and the police offered little protection. In response to a request from Hanna, James Connolly (1868-1916) came from Belfast to Dublin in 1912 to speak in favour of women's suffrage and free speech, and he ensured that the ITGWU (Irish Transport and General Workers' Union) supported both. As another feminist noted at the time, 'he taught the Transport Union of Dublin to support and respect the women workers' struggle for industrial and political rights'. ${ }^{23}$ Hanna was arrested later that year for disrupting a visit to Dublin of the British Prime Minister, Herbert Asquith (1852-1928). She was dismissed from her job at Rathmines College. In the next year, 1913, Hanna was back in prison, briefly, and on hunger strike, for a peaceful protest during a visit to Dublin of Arthur Bonar Law 
(1858-1923), the leader of the Conservative Party. She campaigned against any subordination of the women's movement to nationalist goals and she opposed with vehemence Britain's drift towards war. In 1916 she acted as messenger and delivery person for the rebels. She refused to take up cooking their meals. She was now a politician of international standing and was slated to be one of the five members of a provisional government had the uprising succeeded. ${ }^{24}$ But 1916 brought deep personal suffering. Frank, opposing all violence but wishing the rising to have a high moral tone nevertheless, was running about Dublin trying to organize a citizens' militia to stop all looting. He was arrested together with two other journalists. All were shot dead in custody. Hanna spent the rest of 1916 forcing the British to hold an inquiry. It never reported.

After the rising, she became more actively involved with a republican movement her pacifism had caused her previously to distrust. In 1917 she went to the United States and, upon the request of Constance Markievicz (1868-1927) and other nationalists, she became the only Irish republican to get an interview with the President. She also raised a lot of money speaking for the republican cause and smuggled this back to Michael Collins (1890-1922). It was on returning from this political mission that she was arrested and sent to join the others at Holloway. After her release from prison in September 1918 she joined the insurrectionary nationalist party, Sinn Féin. In 1919 she was elected a councillor for Dublin city. She opposed the treaty with Britain that created the Irish Free State because the Irish parliament was still required to be loyal to the crown. She attacked the Free State for its shooting of POWs during the civil war of 1922-3 and she spent much of this period in the United States explaining the anti-treaty position to Irish-Americans. She defended the idealism of the 1916 and led the public protests against Séan O'Casey's (1880-1964) The plough and the stars of 1926 when it presented the rebels as drunk and vainglorious. Her second in the debate was Maud Gonne (1866-1953). In 1926 when the Fianna Fáil party was formed by Éamon de Valéra (1882-1975), she was put on its executive but, like all women, was excluded from the policy-making inner circle and soon resigned. She was always openly critical of de Valéra's failure to advance women's issues, and she continued to work for socialism and world peace until she effectively retired from public life through illness in 1937.

\section{From cultural nationalism to the rights of prisoners}

The other three jailbirds had been taken from their homes in Dublin as part of a cull of 73 nationalists on 17 and 18 May 1918. After Sheehy Skeffington, the next was not freed until October when the mortal illness of Maud Gonne MacBride secured her release. ${ }^{25}$ The influenza pandemic had begun its march through the institutional populations of Britain and threatened the weakest among them. Maud had been born in England, her father being an officer in the British army. Her ancestors were Irish and she spent part of her childhood in Ireland. In 1887 she met and fell in love with a married French nationalist, Lucien Millevoye (1850-1918). They promised to dedicate themselves to the 
return of Alsace-Lorraine to France and to the liberation of Ireland from England. In 1888 she approached the famous Fenian, John O'Leary (1830-1907), to ask what she might do in Ireland's cause. At this time there was no nationalist organization that she could join since all prohibited the membership of women. Although not a member of any society, she campaigned in the press and gave poetry readings at nationalist meetings. In 1889 she met William Butler Yeats (1865-1939) in London and, ignorant of her affair with Millevoye, he fell desperately in love with her, promising to write a nationalist play, The Countess Cathleen, so that she might fulfil her wish to act in Dublin. In January 1890 Gonne gave birth to a son. In the eyes of the Church Millevoye was still married to his wife. The child, named George, stayed in France out of sight, and died in August 1891. About this time, Gonne became deeply involved with mysticism. She spent much of each year in France, particularly after the birth of a daughter, Iseult, in 1894. To folks in Ireland she explained this away as an adoption.

The 1890 s saw her campaigning: in England and Scotland on behalf of the treasonfelony prisoners suffering abuse in Portland; in the United States to raise money both for a monument to Theobald Wolfe Tone (1763-98) and for the amnesty campaign for the Fenian prisoners; in France to evangelize on behalf of the cause of Ireland; and in Ireland against all signs of acquiescence in British rule. With James Connolly, she protested the visit of Queen Victoria (1819-1901) to Dublin in her jubilee year of 1897. She was on the committee for celebrating the centenary of the United Irishmen's rising of 1798. She publicized the evil of the eviction of tenant farmers in Donegal in 1890 and drew attention to the danger of famine in Mayo in 1898. In October 1899 she was central in campaigns against the Irish volunteering to serve with the British in the Boer War. To counter the anti-recruiting campaign, Victoria came again to Dublin in April 1900. Gonne organised a picnic for patriotic children in response to the loyalist equivalent planned for 5000 in Phoenix Park. Some 30000 children attended Gonne's picnic and the women who had organized it with her became the core of the new society she formed: 'I called a meeting of all the girls who, like myself, resented being excluded as women from National Organisations. Our object was to work for the complete independence of Ireland. ${ }^{26}$ The new group was called the Inghinidhe na hÉireann (Daughters of Erin/Ireland) and as late as 1907 it was described by Kathleen Clarke (1878-1972) as the only revolutionary organization in Ireland. ${ }^{27}$ This society staged the play that Yeats and Lady Augusta Gregory (1852-1932) wrote about one of the most famous female symbols of Ireland, Kathleen Ní Houlihan and the part was played, with great success, by Gonne at its first staging in 1902: 'I did it because it was only on that condition that Willie Yeats would give us the right of producing his play, and I felt that play would have great importance for the national movement. ${ }^{28}$ Late 1900 saw her collaborate with Arthur Griffith (1871-1922) in creating Cumann na nGaedheal (Irish Council) as an openly militant nationalist organization not relying upon any secret societies. Members of the Inghinidhe were incorporated as equal members within this new group. When Edward VII (1841-1910) announced that he would visit his subjects in Dublin in July 1902, Gonne organized a committee to ensure that pressure was put on the mayor of Dublin to live up to his nationalist pretensions and refuse to present the new king with a loyal address. She objected to any 
representation of the Irish as vulgar, seeing them instead as a spiritual people. Thus she walked out of John Millington Synge's (1871-1909) social realist play, Shadow of the glen, and she told Yeats that Synge's Playboy of the western world had done harm to the Irish cause in Paris for the audience 'went away thinking that the Ireland they had dreamed of was after all only a dirty place filled with drunken criminal people little better than savages'. 29

Alongside the Boers, an Irish brigade had fought the British in the Transvaal. Its commanding officer had been John MacBride (1865-1916), and he came to exile in Paris in late 1900. Gonne admired this man who had actually led Irish people into action against British guns. She went to the United States with him in February 1901 to help him give the speeches that it was hoped would raise money to arm Ireland. Gonne became a Catholic and married MacBride in Paris in February 1903. This alliance of heroes was very popular among nationalists but when, after the birth of a son, Séan, Gonne ended the marriage on account of MacBride's drinking and his abuse of his stepdaughter, she found herself anathematized in many nationalist circles. She was also afraid to live in Ireland with Séan in case MacBride snatched him. On her visits to Ireland she was involved with the creation of a newspaper for the Inghinidhe, Bean na bEireann (Women of Ireland). She campaigned for Ireland's inclusion under the 1906 Act that allowed local authorities to provide free school meals on the rates. All four of the internees of 1918 worked from 1910 for the committee that raised funds to feed poor Dublin school children. In 1914, the 1906 Act was indeed extended to Ireland. During the 1913 lockout she raised money so that strikers could reclaim their clothes from the pawn. 1914 saw her trapped in France by the war and together with Iseult she nursed French troops at the front line. Thus she was absent from Dublin when the Easter Rising of 1916 occurred. She immediately saw the 'tragic dignity' of the rebellion and expected that in the conference at the end of the war where the rights of small nations will be talked of, it will be impossible to ignore Ireland'. ${ }^{30}$ John MacBride had played no part in planning the rebellion but he immediately volunteered once it had begun. Arrested by the British, after the surrender he was executed. By his sacrifice he had been able, in her eyes, to 'atone for all'. 31

In 1918 she returned illegally to Ireland, where her immediate involvement in the anti-recruiting campaign marked her out for arrest in May. After her release, in October, she continued to campaign on behalf of the republican prisoners, but the distaste for violence engendered in the battlefield hospitals of France kept her out of Sinn Féin. She did, however, work with the Sinn Féin underground government helping Desmond Fitzgerald (1888-1947), the minister for propaganda, produce the Irish Bulletin. With Markievicz and other women prominent in politics, she signed an appeal to the women of other countries asking them to demand an international committee of inquiry into the conditions under which republican prisoners were held in British jails. In 1920 an American Commission on Conditions in Ireland documented the appalling circumstances of detention. Unlike Clarke, Markievicz and Sheehy Skeffington, she had at first seen some potential in the treaty. She was not overly concerned about the form of the oath of allegiance, thinking full independence could soon be asserted when British troops had left Ireland. When the debate over the treaty broke down she joined Sheehy 
Skeffington and other women in a peace committee trying to broker a non-violent resolution. But when the civil war began she again took up her work on behalf of prisoners, in opposition this time to an Irish Free State that had some 12000 republicans behind bars. The Women's Prisoners Defence League was banned early in 1923 and by April she was in prison again; this time only for three weeks, for she went immediately on hunger strike. She spent the rest of her life campaigning for peace and on behalf of prisoners.

\section{From backdoor influence to social activism}

Though sick and weakening, Kathleen Clarke did not have the powerful connections that worked for Gonne's release. She stayed in prison four months longer, being released in February 1919. She was born in Limerick into a revolutionary family. ${ }^{32}$ Her uncle, John Daly, was a Fenian, imprisoned many times and subject there to the brutality of solitary confinement, sleep deprivation, short rations and frequent beatings. In prison, John Daly's emotional support had been Tom Clarke (1858-1916), a man who endured this treatment for fifteen years and refused ever to beg for an amnesty. On his release from prison in 1898, effectively on probation, Clarke went to stay with Daly in Limerick and there met Kathleen Daly, who at 20 was half his age. Unable to get work in Ireland, Clarke went to the United States in 1900. Kathleen joined him in 1901 and they married. In 1907, Tom Clarke became convinced that England must soon be at war with Germany and that England's difficulty could prove Ireland's opportunity. Tom and Kathleen returned with their children to Ireland, and defied the threat of imprisonment to engage in politics. Tom began to work at animating the moribund Irish Republican Brotherhood, an oath-bound, secret and insurrectionary group known also as the Fenians. Clarke, a veteran of bombing campaigns and British prisons, had the respect of all Irish revolutionaries, and he forged alliances where competition and lack of trust had ruled. He decided that the IRB should infiltrate the leadership of all nationalist and republican groups and plan in secret for an uprising. When first married, Kathleen had accompanied Tom to meetings, but with three young sons and no money for servants, she soon became a confidante at home rather than a comrade in public.

The 1916 rising was planned by the military council of the IRB (Tom Clarke, Joseph Plunkett (1887-1916), Patrick Pearse (1879-1916), Séan MacDiarmada (1884-1916), Thomas MacDonagh (1878-1916)) plus, from early 1916, James Connolly). The overall leadership lay with Clarke. He was the one in touch with John Devoy (1842-1928) and thus with the American money through which it was hoped to arm the rebels. Each leader had a 'ghost' and Tom's was Kathleen. Were Tom to be arrested, Kathleen had been briefed to take over. It was to her that Devoy and the others should refer and defer in Tom's absence. Kathleen knew everything: the chain of command, the bank accounts, the military strategy and the fact that the Rising was only likely to prevail for a short time. As she expected, Tom did not survive. After the surrender he was executed. Kathleen now took over the management of the IRB funds, using them to organize relief to the dependants of the thirteen executed, the dozens killed in action and the 
thousands jailed. She retained this position after the IRB activists were released in 1921 and when the Irish White Cross was set up to distribute extensive new funds from North America, its executive included Clarke, Gonne and Sheehy Skeffington. With the republican leaders dead or in prison, it was the relief work and the amnesty campaign, which she also directed, that kept the independence movement alive. In 1917 she was one of four women elected to the Sinn Féin executive. Constance Markievicz was another. ${ }^{33}$ Then, in May 1918, came her internment in Holloway.

In defiance of British rule, the first Dáil declared independence on 21 January 1919 and began to create parallel institutions alongside those of the English colonial administration. Kathleen, like Hanna Sheehy Skeffington and Maud Gonne, acted as a judge in the new republican courts. She adjudicated cases involving women and children in north Dublin. Late in 1919, Clarke was a successful Sinn Féin candidate in local government elections. In 1921 she was elected for Sinn Féin a member of the second Dáil. When the treaty of December 1921 was debated in the Dáil, Kathleen was opposed to it. The vote was lost and she then began encouraging the IRB to take up again armed struggle. Civil war ensued as both the constitutional and insurrectionary nationalists divided within themselves. She was next elected to the third Dáil in 1925 as a Fianna Fáil candidate and then as a senator to the upper house, where she opposed every socially conservative act of Éamon de Valéra's (1882-1975) government. In 1939 she became the first woman to be lord mayor of Dublin. She resigned from Fianna Fáil in 1941 and more or less left public life.

\section{From nationalism to socialism}

The first detained and the last released of these four internees was Constance Markievicz. ${ }^{34}$ Her family were paternalistic aristocrats in Sligo. Her younger sister Eva Gore Booth (1870-1926) became a committed feminist and pacifist. In 1896 Constance, Eva and their youngest sister, Mabel, set up a Sligo branch of the Women's Suffrage Society. Studying art in Paris she met a Polish count with similar cultural enthusiasms. They were married and, after a visit to his estates in Poland, they tried to settle in Dublin. In 1908 she played the title role in Edward Martyn's Queen Maeve, and in order to research its background began to read about the national and agrarian questions in Ireland. ${ }^{35}$ She then joined Sinn Féin and also Gonne's Inghinidhe na hÉireann. In 1909, against the wishes of the non-militant Arthur Griffith and Sinn Féin, she set up a nationalist version of the scouts, Fianna na hÉireann, and she began organizing camps, military drill and nationalist education for her boys. The Fianna were taken over, in matters of military direction, by the IRB. In defiance of the IRB, she set up some branches for girls. By now she was working full-time in the nationalist cause; she gave up her daughter to be raised by her mother and was resigned when her husband returned to eastern Europe in 1913.

Markievicz was influenced strongly by Connolly to see nationalism as a means towards other social and economic freedoms. Thus, she was an early supporter of the Irish Women Workers' Union established in 1911 by Delia Larkin (1878-1949) 
and her brother James (1876-1947). In 1913, Constance worked to aid the ITGWU as it endured a lockout of thousands of members in Dublin: 'Throughout the city of Dublin she organised a series of food kitchens, milk depots, and clothing stations which undoubtedly saved the strikers' families from starvation. ${ }^{36}$ At this time, Connolly formed an Irish Citizens Army to defend protesting workers against attack. Markievicz joined. The ICA took men and women on equal terms. As the British moved towards passing a Home Rule Act for Ireland, Edward Carson (1854-1935) formed the Ulster Volunteers, promising armed defiance. In reaction, the nationalists formed the Irish Volunteers, Excluded from membership, women set up a council (Cumann na mBan, Women's Council) to assist in permissible ways (primarily fundraising, nursing and cooking). Markievicz joined. By 1916 she was prominent in the women's, nationalist and the labour movements of Ireland. She was particularly close to James Connolly and was, with Michael Mallin (1880-1916), Connolly's ghost, as Kathleen was Thomas Clarke's. She drew the maps that were used to plan the Rising. She fought with the ICA in Easter week. Sent with supplies to Stephen's Green on Easter Monday, the first day of the rebellion, she stayed there first as a sniper and then as Mallin's second in command. It was in this capacity that she surrendered the following Saturday in obedience to an order from Connolly. She was tried by court martial for treason. The verdict was stark: 'Guilty. Death by being shot. The Court recommend the prisoner to mercy solely and only on account of her sex. ${ }^{37}$ She was released from prison a year later, on 28 June 1917.

Then, in May 1918, and probably because of her prominence in the anti-recruiting campaign, the British arrested her again and sent her to Holloway. She was still interned without charge in prison when the general election came in November 1918. For the first time, women over 30 could vote. She was nominated as Sinn Féin candidate for a Dublin constituency and, after a campaign ignored by the men of Sinn Féin but prosecuted with energy by feminists, became the first woman elected to the British parliament. ${ }^{38}$ Together with the rest of Sinn Féin, she did not attend in London. In the local elections of 1919 she was also elected and went to the first Dáil. There she demanded a cabinet post, telling the Sinn Féin leadership that 'she had earned the right to be a minister as well as any of the men, and was equally as well fitted for it, educationally and every other way, and if she was not made a minister she would go over to the Labour Party'. ${ }^{39}$ Invaluable as a mediator between republicans and socialists, she was appointed minister of labour, the first female cabinet minister in Western Europe. In common with the rest of the Republic's government, she was harrassed by the British state. In June 1919 she met with a delegation from the United States that made representations about Ireland to the Paris peace conference. Within a week she was arrested by the British on a charge of running the Fianna na Éireann as a secret conspiracy. She was given four months' hard labour in Cork prison before being transferred to Mountjoy prison until June 1921. In the 1921 debate over the Treaty with Britain, she spoke against what she saw as an invalid compromise. She was soon an enemy of the Free State. Campaigning in 1923 on behalf of imprisoned republicans, she and Gonne were arrested. When she died, in 1927, the Free State refused to honour her as one of Ireland's heroic freedom fighters. 


\section{Symbols: women and political practice}

Sheehy Skeffington, Gonne, Clarke and Markievicz contributed in diverse ways to nationalist politics in Ireland and they inflected that involvement with commitments to other principles too. Figure 2 shows some of the causes for which they worked together and separately. Markievicz was the most involved with Labour and Sheehy Skeffington the most with feminism. Gonne and Clarke were central to the campaigns on behalf of prisoners, while Sheehy Skeffington and Gonne were prominent in the peace movement. It is clear that each was committed both to nationalism and to the pursuit of women's rights. Sheehy Skeffington discounted the cultural nationalists who said that restoring Gaelic values would inevitably aid women since their status in the ancient society had been more elevated than in the modern. In 1918 Sinn Féin had promised that 'as in the past, so in the future the womenfolk of the Gael shall have high place in the Councils of a freed Gaelic nation' ${ }^{40}$ She was unimpressed with such appeals to history:

Some Celtic enthusiasts hold the average Irishman very high above petty sex spite and prejudice and quote Irish traditions of womanhood in support of the theory. One learns, however, to distrust this thriftless Irish habit of living on the reputation of its ancestors, especially when one is faced with the problems of Ireland today. ${ }^{41}$

For Sheehy Skeffington, it was only Connolly's promise that the Proclamation of Independence would include equal rights for women that drew her to support the planning for 1916 despite her pacifist principles. Indeed, had there been a provisional government established by the rebels, she was to have been one of its five members. ${ }^{42}$ She had earlier dismissed Cumann na mBan as 'an animated collecting box' since its members had no say in how Sinn Féin spent the funds it raised. ${ }^{43}$ In contrast, Markievicz disagreed with the Irish Women's Franchise League because its demands were limited to the franchise and did not include Irish independence. ${ }^{44}$ However, she was equally critical of Arthur Griffith and Sinn Féin because they relegated female suffrage to the social questions they wished to defer until after independence.

It is also clear that these women had to struggle for access to the political realm. In Walby's terms, they had to fight both the private patriarchy of being told that their place was in the home and the public patriarchy of being told that their public place was as men's helpmates rather than equals. ${ }^{45}$ Sheehy Skeffington underlined the differences between Connolly and de Valéra in stark terms: 'To the one, woman was an equal, a comrade: to the other, a sheltered being, withdrawn to the domestic hearth, shrinking from public life. ${ }^{46}$ In this regard, de Valéra wanted Markievicz remembered as a philanthropist rather than as a revolutionary. Sheehy Skeffington was incensed with the behaviour of this man she described to Markievicz's sister, Eva, as 'essentially conservative and church-bound, anti-feminist, bourgeois and the rest'. ${ }^{47}$ Women seeking a political role could from 1883 pursue cultural nationalism through the Gaelic League. In an interview with an American journalist in 1906 Lucy Hyde, the wife of Douglas, the League's president, insisted that ' $t$ ]he great advantage of the League' was its giving women 'as much scope for their activity as men'. ${ }^{48}$ The council of the Gaelic League in 1895 
SHEEHY SKEFFINGTON GONNE

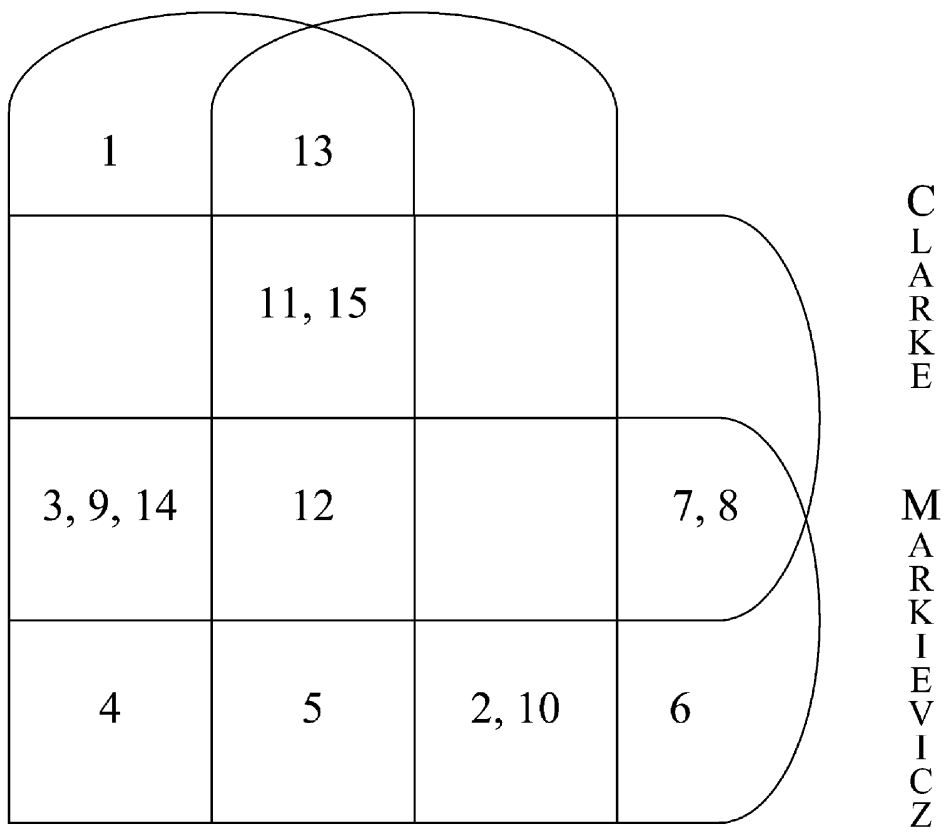

1. Irish Women's Franchise League 1908

2. Inghinidhe na hÉireann 1900

3. School Feeding Committee 1910

4. Irish Women's Workers Union 1911

5. Meals for children and families during the Lockout 1913

6. Irish Citizen's Army 1913

7. Cumann na mBan 1914

8. Sinn Féin executive 1917

9. Sinn Féin underground government and courts 1919-21

10. Appeal for International Inquiry into treatment of Irish prisoners 1919

11. White Cross Committee 1921

12. Women's Prisoners' Defence League 1922

13. Committee negotiating for peace between pro- and anti-Treaty factions 1922

14. First Executive of Fianna Fáil 1926

15. Opposition to 1937 Constitution 1937

FIGURE 2 The political campaigns of the revolutionary sisters 
counted three women among its twenty members but its nine elected officers were all men. ${ }^{49}$ From 1905 women could participate in the political nationalism of Sinn Féin. ${ }^{50}$ The Irish Parliamentary Party, however, was closed to them. Secret societies such as the Irish Republican Brotherhood forbade the presence of women, although Una Bolgar was a sworn member because her fiancé, Robert Brennan (1881-1964), refused to have any secrets from her. ${ }^{51}$ Maud Gonne was also a sworn member because she convinced Dr Mark Ryan (1844-1940) that she already knew so many of its secrets. ${ }^{52}$ In the Labour movement James Larkin and James Connolly both promoted a range of social issues including equality for women. Thus women were accepted in the ICA and at least five were officers. In contrast the Irish Volunteers had no women under arms. Even the fundraising efforts of the Cumann na mBan were replaced by a new Irish Volunteer Aid Association under male direction when John Redmond's parliamentarians were brought into the Volunteers. ${ }^{53}$ These exclusions hurt. Gonne told one parliamentarian that she hated 'this exclusion of women from the National fight, and the fact that they should have to work through backdoor influence if they want to get things done'. ${ }^{54}$ In the 1916 Rising, the defence of Dublin was consigned to Connolly and he ordered the Volunteers to accept the assistance of armed women from the ICA and unarmed women from the Cumann na mBan. Perhaps 200 women were involved in Dublin and 77 were arrested. ${ }^{55}$ Ominously, it was the future head of government, de Valéra, who was the only rebel leader to refuse point-blank to fight alongside women, and thus the women refused to serve as nurses and cooks to his men at Boland's Mill. However, with so many men and a few women in prison for much of the period between 1916 and 1921, the republican movement and the underground Sinn Féin government relied upon the active and public participation of women. Markievicz as Minister of Labour brought many other Cumann na mBan women into the administration: 'My getting locked up has done more to bring women out into the open than anything else. The shyest are ready to do my work when I'm not there. ${ }^{56}$ When the surviving rebel leaders were released from prison with the truce in 1921, Griffith and de Valéra in particular tried to make do with a mere token female presence in government, but women such as Kathleen Clarke refused this purely symbolic role. When de Valéra wanted only one woman among the Sinn Féin senators in 1925 she would not stand down in favour of Mrs Pearse. Clarke told de Valéra that she 'could see no reason for the Party refusing to support two women, when women had played such a big part in the fight for freedom'. ${ }^{57}$ Jenny Wyse Power (1858-1941), of Cumann na Gaedheal, voted across party lines to ensure Clarke's election.

Kandiyoti has noted that where women play a symbolic role in nationalist discourse, their citizenship can be compromised by the patriarchal values at the heart of many forms of ethnic identity. ${ }^{58}$ For the sake of the purity of the race or nation, women are told they should abjure the hurly-burly of politics. Yet symbols do not secure patriarchy. The selection and interpretation of symbols is tested and developed through their use. Maud Gonne was a beautiful woman before she played the part of Kathleen Ní Houlihan. ${ }^{59}$ She was also, like Markievicz, a glamorous member of the upper classes who adopted the cause of the oppressed. Although Yeats had his own reasons for opposing her marriage to John MacBride and his analysis of her potential loss of caste 
through the marriage ignored the heroic status of MacBride, nevertheless his account of the role of class in Gonne's appeal to the Irish poor had more than a grain of truth:

You possess your influence in Ireland very largely because you come to the people from above. You represent a superior class, a class whose people are more independent, have a more beautiful life, a more refined life. Every man almost of the people who has spoken to me of you has shown that you influence him very largely because of this. Maud Gonne is surrounded by romance. She puts from her what seems an easy \& splendid life that she may devote herself to the people. I have heard you called 'our great lady'. 60

Yeats saw this as the natural authority of the aristocracy but it was at least as much about self-sacrifice. What Gonne and Markievicz had given up established their sincerity. It was Gonne's beauty and her passion that provoked Millevoye to exclaim when first her met her: 'Why don't you free Ireland as Joan of Arc freed France? You don't understand your own power. ${ }^{61}$ It was the military reputation of the saint that drew Markievicz to her image when in 1909 she asserted that Ireland needed its own Joan of Arc to set it free. ${ }^{62}$ Indeed in the tableaux vivants that Inghinidhe na Éireann put on she would often dress herself in armour as the French saint. The martial Queen Maeve was equally important to these women. Markievicz named her own daughter Maeve, and Gonne took this as her code-name within the Inghinidhe. The Inghinidhe and later (1917) the association of women representatives within Sinn Féin, Cumann na dTeachtaire, were placed under the protection of St Brigid for, as Markievicz wrote, 'such a good suffragist should get recognition'. 63

Symbols, therefore, sustained the women in their political practice. Markievicz was explicit about this: 'I know it was a common sneer in England at one time that we could not talk of Ireland in Plain English. It was always "Kathleen Ní Houlihan" or some other unprounouncable name, and her "four green fields" gave great offence too. Now I like all that. ${ }^{64}$ She regularly personified Ireland as Kathleen and not only to get political messages past the prison censor: 'Kitty seems to be having a great look-in just now. Everyone seems to want her. I think she will get her divorce in the end. ${ }^{, 65}$ When Gonne played Kathleen in the play by Yeats and Gregory, the symbolic importance of both Gonne and Kathleen were significant. Another actress in that production recalled: 'Watching her, one could readily understand the reputation she enjoyed as the most beautiful woman in Ireland, the inspiration of the whole revolutionary movement. ... She was the very personification of the figure she portrayed on the stage. ${ }^{, 66}$ The play ends with Kathleen praising the sacrifice of the young men who are to give their lives for her. At the time, Stephen Gwynn (1864-1950) reflected upon Yeats's responsibility: 'I went home asking myself if such plays should be produced unless one was prepared for people to go out to shoot and be shot. ${ }^{, 67}$ In the wake of 1916, many people returned to those lines. In prison, Markievicz quoted from the play in a letter to her sister, Eva Gore Booth: "What we stood for, and even poor me will not be forgotten, and "the people shall hear them for ever?" That play of W.B.'s was a sort of gospel to me. "If any man would help me, he must give me himself, give me all". ${ }^{68}$ Returning to Gwynn's worries, Yeats himself wondered with regret: 'Did that play of mine send out | Certain men the English shot? ${ }^{69}$ Again, it is the notion of self-sacrifice that matters, and although the representation is gendered, the appeal is quite clearly to both men and women. 
Visions of Kathleen were associated with sacrifice before and after the success of the play. Louie Bennett (1870-1956) recorded in a notebook that her selfless commitment to the cause of Labour and then Nation rested upon a recurring vision:

Saw Kathleen Ní Houlihan. Not with one's eyes one sees a spirit. No man knows how he sees it. But suddenly I saw Kathleen Ní Houlihan and understood her history. Saw her ragged, old, feeble, barefooted. Saw her beautiful wild eyes - heard her beautiful wild song, saw her everlasting youth and unconquerable soul. ... [M]aybe its something she whispers to you, or maybe she just touches you, or maybe she does nothing at all but just stands by you. But, however it is, from that day on she's got you for hers, and come life or come death, the spell is on you. ... And I, with romance as I thought for ever dead for me, come to a new sense of romance. I have caught the secret and so, for me, life has a new beauty. I have come into a new Kingdom. And now I understand. And I understand what it is gives an edge to life for the labourer - and for the working man. ${ }^{70}$

This is a remarkable conflation of the romantic and the sacred. In 1913, at the time of her first vision, Bennett was 43 years old. An image that could plumb such depths is indeed powerful. Gonne was sustained by a similar memory of a vision and in her 70 s she wrote it down recalling an incident from her early 30s (1898). At twilight, in a train crossing boglands in Mayo where she had been working to mitigate the effects of a potato blight, Gonne:

[S]aw a tall beautiful woman with dark hair blown on the wind and I knew it was Cathleen ní Houlihan. She was crossing the bog towards the hills, springing from stone to stone over the treacherous surface, and the little white stones shone, making a path behind her, then faded into the darkness. I heard a voice say 'You are one of the little stones on which the feet of the Queen have rested on her way to Freedom'. The sadness of the night took hold of me and I cried; it seemed too lonely just to be one of those little stones left behind on the path.

Being old now and not triumphant I know the blessedness of having been 'one of those little stones' on the path to Freedom. ${ }^{71}$

The spirit world was a very real presence for many of these women. A broadly pagan pantheism connected them, and their male contemporaries, to the rocks, soil and ancient goddesses of Ireland. Sheehy Skeffington told her son, Owen, that she was a pagan and wanted a pagan funeral. ${ }^{72}$ Markievicz found comfort in a mystical abnegation in the face of nature:

[S]omehow in the hour of twilight the dividing lines that one imagines between oneself and Nature seem to melt away. One feels one with - or rather an indissoluble atom of Nature - of Life and Death. ... We have but scanty records of the brave deaths men have died for Ireland, but this we know: every hillside, every valley, each cornfield, and grazing ranch, every potato patch, bog, town, or lonely cottage has its own story to tell us, a story of oppression and murder, tyranny and starvation, met with self-sacrifice and martyrdom .$^{73}$

With Gonne, this connection with the spiritual world was an essential source of support for any activist:

I believe that every political movement on earth has its counterpart in the spirit world and the battles we fight have perhaps been already fought out on another plane and great leaders draw their often unexplained power from this. I cannot conceive a material movement which has not a spiritual basis. ${ }^{74}$ 
Gonne saw occult research as a valid if dangerous way to tap these powers. Although she later converted to Catholicism, as did Markievicz, the better to identify with the spiritual life of the people on whose behalf she fought, the pagan goddesses remained powerful for her. They clearly offered an alternative to patriarchal readings of Christianity. Markievicz's sister, Eva Gore Booth, thought that male and female traits were found in both genders and that sexism had been introduced into the Bible in the course of its successive translations. ${ }^{75}$ Markievicz herself appealed to women to get in touch with their masculine side:

A consciousness of their own dignity should be encouraged to get away from false standards of womanhood, to escape from their domestic ruts, their feminine pens. It would be well to aim at bringing out, as it were, the masculine side of women's souls. ... We have got to get rid of the last vestige of the harem before woman is free as our dream of the future would have her. ${ }^{76}$

Instead of seeing herself as Yeats's passive muse, Gonne argued that it was by denying him the solace of marriage that she had given him the gift of suffering out of which he had forged his art: 'Our children were your poems of which I was the Father sowing the unrest \& storm which made them possible \& you the mother who brought them forth in suffering \& in the highest beauty \& our children had wings. ${ }^{77}$

These women are trying to counter the double standard that would venerate women as symbols but relegate them as citizens. They seem to have taken genuine comfort from gendered images of sacrifice. They see this sacrifice as an appeal from the feminine in Ireland to the militant masculine in Ireland. Yet they insist that these traits are present in both men and women. Replying when she was told she could not, as a woman, join the National League in 1888, Gonne exclaimed: 'Surely Ireland needs all her children. ${ }^{78}$ The women hoped that gendered images of sacrifice would comfort both men and women. Writing of the executed republican hero Roger Casement (1864-1916), Eva Gore Booth imagined him hearing the call of Ireland as he came with guns from Germany: 'I dream of him hearing the voice, | The bitter cry of Kathleen ni Houlighan | On the salt Atlantic wind. ${ }^{79}$

Sacrifice may be taken as characteristic of the Gael but it is neither the prerogative of one sex only nor unthinking, blind and irrational. Yeats famously wrote that 'Too long a sacrifice | Can make a stone of the heart'. ${ }^{80}$ His poem is non-judgemental about the individuals who died in 1916 because by their sacrifice they showed a dignity that elevated them out of the quotidian. Yet he also saw their sacrifice as lifting the causes for which they fought out of rational debate. He implied that the monomaniacal focus upon national independence ossified intelligence: 'Hearts with one purpose alone | Through summer and winter seem | Enchanted to a stone | To trouble the living stream'. ${ }^{81}$ In contrast natural and living things, like the stream, were constantly changing. At the end of the poem, he named the dead individuals to whom he was alluding: 'MacDonagh and MacBride | And Connolly and Pearse'. ${ }^{82}$ Leaving aside her estranged husband, Gonne shot back an immediate response to Yeats's earliest version of this poem:

You could never say MacDonagh \& Pearse \& Conally $[s i c]$ were sterile fixed minds, each served Ireland, which was their share of their world, the part they were in contact with, with varied faculties and vidid energy. Those three were men of genius with large comprehensive \& speculative $\&$ active brains. ${ }^{83}$ 
If post-conflict situations offer a window of opportunity for rethinking the place of women within public and private spheres ${ }^{84}$ then, Yeats's equation of sacrifice with irrationality returned to the customary conflation of the feminine with the emotional reserving the rational for the masculine. These questions were debated again at the founding moment of the Irish Free State, the discussion of the Treaty with Britain.

\section{Practice: gender and symbolism in the treaty debate}

The passivity of women was not secured through the circulation of images, but symbolic women were often evoked as part of explicit attempts to devalue female citizenship. These four women were themselves symbols. Primarily, they became symbols of sacrifice. Three of them were left widows after 1916. By December 1921, when a treaty had been negotiated with Britain, all had been imprisoned at least once. Clarke and Markievicz were deputies in the Dáil when the treaty was debated. All the women deputies were opposed to the treaty. None thought an agreement to remain a dominion of the British crown worth the sacrifice of 1916. The sorrowing women were a potent political symbol and were frequently used as such. Through them, Sinn Féin exploited the legitimacy attaching to the sacrifice made by their male relatives. Yet, when these women spoke for themselves rather than allowed others to speak through them, there were many who felt they had overstepped the mark. Speaking in support of the treaty, Finian Lynch asserted that the bones of the dead have been rattled indecently in the face of this assembly'. ${ }^{85}$ Many deputies argued on the basis of what the republican martyrs they knew so well had stood for. One deputy read a letter from the wife of Terence MacSwiney (1879-1920). MacSwiney, lord mayor of Cork, had died on hunger strike in Brixton prison. The letter told the Dáil that accepting the treaty 'would probably ... be the greatest triumph that the enemy has ever had', and she assured it that 'I am absolutely certain that Terry would have said what I am saying. ${ }^{86}$ Similarly, Margaret Pearse, the mother of Patrick, assured the deputies that as a faithful disciple of Tom Clarke, Patrick would have opposed the Treaty. ${ }^{87}$ Kathleen Clarke recalled that when she met Tom just hours before his execution his message was clear: 'Tell the Irish people that I and my comrades believe we have saved the soul of Ireland. We believe she will never lie down again until she has gained complete freedom. ${ }^{88}$ This treaty was not complete freedom. Séan T. O'Kelly (1882-1966), referring to Terence MacSwiney being buried in the uniform of a soldier of the Republic, avowed: 'That uniform in which our colleague was buried is, to me at least, a sacred thing; nothing less than the habit of a martyr, with a truer title to be so regarded than the purple or scarlet of Bishop or Cardinal; the habit of Francis or of Dominic. ${ }^{89}$ He too opposed the treaty in the name of the dead.

In these ways, the totemic weeping women evoked the sanctity of the cause and were a direct physical link to the martyrs already being elevated to the status of icons to be invoked in support of or, more often, against the treaty. The treaty was clearly a compromise, and few who urged its acceptance really expected the relatives of the dead heroes to be enthusiastic. Kathleen Clarke recalled a conversation with Michael Collins: 
“"Surely Mick you do not expect people like me to vote for such an agreement?" "No", he replied, "Nor would I like to see people like you vote for it." 90 Recalling Tom's words, Collins said that after the treaty had been signed he hoped Clarke would join him in taking up again the fight to secure Ireland's 'complete freedom'. Few supporters of the treaty were this generous to their opponents. Many tried to deny the relatives the right to speak on behalf of the dead. To some degree this devalued the symbolic level altogether. Piaris Béaslaí (1881-1965) asserted, 'A nation is not an arid abstraction. It is a

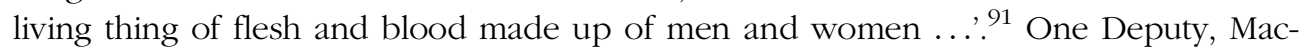
Cabe, went so far as to appeal to the relatives of the dead, 'to rise above their personal prejudices and think of themselves, not as the sisters, or wives, or mothers, or brothers of dead patriots, but as representatives of the people, with the fate of a country in their hands. The earth belongs to those who are on it, and not to those who are under it, and to the living and not the dead we owe our votes. ${ }^{92}$

Now, it was precisely as sisters, or wives, or mothers of dead patriots that four of the six women in the Dáil had secured election. In the private session of the Dáil that preceded the public debate, Margaret Pearse acknowledged that '[s]he had been elected here on account of her beloved boys'. ${ }^{93}$ It was in this capacity that they demanded a hearing. Introducing her own three-hour speech to the private session, Mary MacSwiney (1872-1942), sister of Terence, asserted: 'I stand here in the name of the dead.'94 Kate O'Callaghan, whose husband, Michael, a former mayor of Limerick, had been murdered by the British army despite having no connection with the armed struggle, insisted:

No woman in this Dáil is going to give her vote merely because she is warped by a deep personal loss. The women of Ireland so far have not appeared much on the political stage. That does not mean that they have no deep convictions about Ireland's status and freedom. It was the mother of the Pearses who made them what they were. The sister of Terence MacSwiney influenced her brother, and is now carrying on his life's work. Deputy Mrs Clarke, the widow of Tom Clarke, was bred in the Fenian household of her uncle, John Daly of Limerick. The women of An Dáil are women of character, and they will vote for principle, not for expediency. For myself, since girlhood I have been a Separatist. ${ }^{95}$

Margaret Pearse insisted that "no matter what anyone says I feel that I and others here have a right to speak in the name of their dead" [applause]'. 96 Dr Ada English (1878-1944) attacked the idea that the women.

Only have the opinions they have because they have a grievance against England, or because their men folk were killed and murdered by England's representatives in this country. It was a most unworthy thing for any man to say here. I can say this more freely because, I thank my God, I have no dead men to be thrown in my teeth as a reason for holding the opinions I hold. ${ }^{97}$

But the opponents of the women were insistent. They clearly tried to substitute an abstraction of womanhood for the actual women that faced them. MacCabe's own speech went on to demand support for the treaty as a way to end war with England. He asked the relatives of the dead 'to think of the millions of wives and mothers and sisters who are waiting expectantly for peace, and to picture the disappointment and despair which the news of the rejection of the Treaty will bring into their homes'. ${ }^{98}$ 
At this point Markievicz interrupted: 'Don't speak for the women.' 99 Harry Boland (1887-1922) also challenged MacCabe's argument, insisting that '[t]he people have proved in this fight as strong as their leaders; and so long as the leaders remain strong no demand that you make on the people would be denied - Don't blame it on the wife. If we are prepared to carry on this fight the people of Ireland will support us. ${ }^{100}$ But MacCabe's argument went further than this appeal to absent over present women. The woman he evoked was self-sacrificing to the point of abnegation:

I wonder is there one women in this assembly who could rise to the great opportunity, one woman who would sink her feelings, sink her cravings for vengeance, sink her principles even, and, sacrificing her personality as others sacrificed their lives, vote for the good of her country. Such an act of self-elimination would, in my opinion, appeal to the whole world as an act worthy of a countrywomen of Terence MacSwiney. ${ }^{101}$

In this extraordinary request it is the military nature of men that makes their lives active, their bodies their one true possession that they can surrender in the national interest. For women it is their virtue that they are passively and in silence to lay down for their country. On the contrary, of course, it was precisely their bodies that were the major means of suffragette struggle in Ireland, with hunger strikes and risky public provocations. ${ }^{102}$ McCabe's demand is closer to the literary representation of women, as in Yeats's Countess Catbleen, where Cathleen gives up everything, even her soul, in order to save her tenants from starvation so that as she 'erases herself from the material world of the text, the more potent she becomes as a symbol of the spiritual victory ... of Celtic virtue'. ${ }^{103}$

This dream of silent women was to become Irish social policy, when the men of the gun became the heads of the Free State. From 1922 to 1977, of the 650 people elected as deputies to the Dáil only 24 were women, and all but five of them were themselves relatives of dead patriots or deputies. ${ }^{104}$ It was not until 1979 that Markievicz had a female successor in the Irish cabinet. ${ }^{105}$ The 1922 election was fought on the basis of the old franchise, which allowed men over 21 and women over 30 to vote. Kate O'Callaghan said that '[d]uring these last years of war and terror, these women in their twenties took their share in the dangers. They have purchased their right to the franchise .... ${ }^{106}$ This appeal to the Dáil fell upon deaf ears. Only after debate did de Valéra agree to implement the 1916 proclamation and include equal enfranchisement for women in the 1922 constitution published on the day of the election, too late to enfranchise the younger women. The leaders on both the pro- and anti-treaty sides wanted to take the women out of Irish politics. Sheehy Skeffington thought Michael Collins had a 'soldier's contempt' for women. ${ }^{107}$ De Valera, she thought, showed 'a mawkish distrust of women' ${ }^{108}$ In 1927, when taking from women the obligation to do jury service, the minister of justice, Kevin O' Higgins (1892-1927), said 'it is the normal and natural function of women to have children'. ${ }^{109}$ Speaking to the Dáil in 1922, Patrick Sarsfield O'Hegarty (1879-1955) went further, blaming 'hysterical' women in the Cumann na mBan for fomenting conflict that men would sooner put by: 'Woman's business in the world is with the things of life [. . . but these women busied themselves with nothing but the things of death. ${ }^{110}$ When, in 1937 , de Valéra proposed a constitution that codified the domestic rather than public role of women, the three survivors of the period in 
Holloway were united in opposition. Hanna Sheehy Skeffington referred to the document as 'Fascist proposals endangering [women's] livelihood, cutting away their rights as human beings'. ${ }^{111}$ Maud Gonne said the treatment of women in the proposal 'would damn it in my eyes'. ${ }^{112}$ Kathleen Clarke said that the measure 'robs us of our status enshrined in [the 1916] Proclamation'. 113 The constitution passed anyway.

In conclusion, it is clear that the meaning of 'sacrifice' was contestable. Women acted in diverse ways in the fight for Irish independence and in their eyes they had proved that they deserved equality. Far from being the shrieking harridans of anti-suffragette propaganda, many women, such as Hanna Sheehy Skeffington, acted as go-betweens in the civil war or, like Constance Markievicz, talked with their many supporters to bring the different factions of the freedom struggles closer together. It is clear that Kathleen Clarke was superb at bringing people towards a principled consensus. These women may have been defeated in their attempt to carve a permanent space for women in public life, but socialists too were defeated, as were those who wanted independence so that the Irish language might once again become universal in Ireland. In terms of Figure 1, by taking up a life of political activism, the daily experience of these women repeatedly confounded the distinction between feminine domestic and masculine public space. Their feminism, more than their nationalism, ensured that their political life was perhaps less insular than that of most of their male colleagues: 'There was little that was parochial about their views or thoughts. ${ }^{, 14}$ Even though many of the symbols of Ireland as woman would seem to reinforce the proscriptions their experience denied, in fact these women took great comfort from some of the gendered images of Ireland which they took as speaking both to men and women. In the sphere of political practice, after the topsy-turvy circumstances and contingencies of the revolution, republican men appealed to their own reading of the gendered symbolism of the nation to deny women the possibility of doing what they had already done: proving that they could be effective in the public spaces of civil society as soldiers, judges, workers and politicians.

The women were not defeated by symbolism. They were beaten down by an alliance of priests and former guerrillas who passed laws to restrict their right to work, to control their bodies and to exercise citizenship. The solidarity forged by women in the suffrage struggle and the bonds between men and women created among those labour and nationalist activists inspired by James Connolly confronted other solidarities nurtured by all-male fighting groups, sex-segregated prisons and an anti-feminist ideology that defended gender inequality as compensation for other defeats, over Partition and over the swearing of an oath of loyalty to the British king. ${ }^{115}$ The symbols themselves, although biased, could bear more than one reading. It was political practice grounded in daily experience that ensured that one of those readings became a silent one.

\section{Acknowledgements}

I would like to thank Tristan Clayton, Stuart Corbridge, Millie Glennon, Phil Howell, Steve Legg, Denis Linehan and Ray Ryan for their comments and advice. 


\section{Notes}

1 Elizabeth Butler Cullingford, Ireland's others: gender and ethnicity in Irish literature and popular culture (Cork, Cork University Press, 2001), p. 4.

2 Maria Tymoczko, The Irish 'Ulysses' (Berkeley, University of California Press, 1994), p. 97.

3 Catherine Nash, 'Embodied Irishness: gender, sexuality and Irish identities', in Brian Graham, ed., In search of Ireland: a cultural geography (London, Routledge, 1997).

4 Nuala Johnson, 'Cast in stone: monuments, geography, and nationalism', Environment and planning D: society and space 13 (1995), pp. 51-65.

5 Cullingford, 'Thinking of Her ... as ... Ireland": Yeats, Pearse and Heaney', Textual practice 4 (1990), p. 12.

6 Tricia Cusack, 'Janus and gender: women and the nation's backward look', Nations and nationalism 6 (2000), p. 558.

7 Eavan Boland, A kind of scar: the woman poet in a national tradition (Dublin, Attic Press, 1989), p. 24.

8 Carol Coulter, The hidden tradition: feminism, women and nationalism in Ireland (Cork, Cork University Press, 1993).

9 This, the popular phonetic spelling of the Irish for 'poor old woman' (sean bhean bhocht), was the name taken by Alice Milligan and Anna Johnston for the feminist and republican newspaper they published in Belfast from 1896 to 1899.

10 Maria-Elena Doyle, 'A spindle for the battle: feminism, myth and the woman-nation in Irish revival drama', Theatre journal 51 (1999), p. 40.

11 Michael Billig, Banal nationalism (London, Sage, 1995).

12 Yvonne Whelan, 'Monuments, power and contested space: the iconography of Sackville Street, Dublin, before Independence (1922)', Irish geography 34 (2001), pp. 11-33.

13 Sallie Marston, 'Public rituals and community power: St Patrick's day parades in Lowell, Massachusetts', Political geography quarterly 8 (1989), pp. 255-77.

14 Angela Martin, 'The practice of identity and an Irish sense of place', Gender, place and culture 4 (1997), pp. 89-119.

15 Sarah Radcliffe, 'Gendered nations: nostalgia, development and territory in Ecuador', Gender, place and culture 3 (1996), pp. 5-21.

16 Lynn A. Staeheli and Albert Thompson, 'Citizenship, community and struggles for public space', Professional geographer 49 (1997), pp. 28-38.

17 Catherine Nash, 'Men again: Irish masculinity, nature, and nationhood in the early twentieth century', Ecumene 3 (1996), pp. 427-53.

18 Angela Martin, 'Death of a nation: transnationalism, bodies and abortion in late-twentieth century Ireland', in Tamar Meyer, ed., Gender ironies of nationalism: sexing the nation (London, Routledge, 2000), pp. 64-86.

19 Lorraine Dowler, "And they think I'm just a nice old lady": women and war in Belfast, Northern Ireland', Gender, place and culture 5 (1998), p. 161.

20 Margaret Ward, Unmanageable revolutionaries: women and Irish nationalism (London, Pluto Press, 1995 [1989]), p. 58.

21 Linda Connolly emphasizes these continuities in The Irish women's movement from revolution to devolution (Basingstoke, Palgrave, 2002).

22 Maria Luddy, Hanna Sheehy Skeffington (Dundalk, Dundalgan Press, 1995); Margaret Ward, Hanna Sheehy Skeffington: a life (Cork, Attic Press, 1997).

23 R. M. Fox, Louie Bennett: her life and times (Dublin, Talbot Press, 1958), p. 45 (letter of April 1916). 
24 The others were Arthur Griffith, Alderman Tom Kelly, Seán T. O’Kelly, and William O’Brien: Brian Maye, Arthur Griffith (Dublin, Griffith College Publications, 1997), p. 342. None of these was directly involved in the Rising, the leaders of which expected to be executed and were hoping to pass their legacy into trustworthy hands while also making it clear that they had acted out of no personal ambition.

25 Margaret Ward, Maud Gonne: Ireland's Joan of Arc (London, Pandora, 1990).

26 A. Norman Jeffares and Anna MacBride White, eds, A servant of the Queen: reminiscences by Maud Gonne MacBride (Gerrards Cross, Colin Smythe, 1994; original edition, Victor Gollancz, 1938), p. 266.

27 Kathleen Clarke, Revolutionary woman: my fight for Ireland's freedom (Dublin, O'Brien Press, 1991), p. 42. Inghinidhe is "[a]n archaic spelling of Inion; both pronounced "Innyeen"” (Mary Kenny, Goodbye to Catholic Ireland: a social, personal and cultural history from the fall of Parnell to the realm of Mary Robinson (London, Sinclair-Stevenson, 1997), p. 297.

28 Ibid., p. 177.

29 Anna MacBride White and A. Norman Jeffares, eds, The Gonne-Yeats letters 1893-1938: 'always your friend' (London, Hutchinson, 1992), p. 330 (Dec. 1913).

30 Quoted in Ward, Gonne, p. 110.

31 Gonne-Yeats letters, p. 375 (11 May 1916).

32 Clarke, Revolutionary woman.

33 In the election of 23 people to the Sinn Féin executive, Markievicz came fourth, Dr Kathleen Lynn tenth, Clarke fifteenth and Grace Plunkett (widow of Joseph) twentieth: Brian P. Murphy, Patrick Pearse and the lost Republican ideal (Dublin, James Duffy, 1991), pp. 93-4.

34 Anne Marreco, The rebel countess: the life and times of Constance Markievicz (London, Weidenfeld \& Nicolson, 1967); Jacqueline Van Voris, Constance Markievicz in the cause of Ireland (Amherst, University of Massachusetts Press, 1967); Sari Okarinen, 'A dream of liberty': Constance Markievicz's vision of Ireland (Helsinki, Suomen Historiallinen Suera, 1998).

35 Gifford Lewis, Eva Gore Booth and Esther Roper, a biography (London, Pandora, 1988), p.135. Maud is the anglicised version of Maeve or Maedh.

36 Sidney Gifford, 'Countess de Markievicz', in Maurice Joy, ed., The Irish Rebellion of 1916 and its martyrs: Erin's tragic Easter (New York, Devin-Adair, 1916), p. 353.

37 Esther Roper, 'Biographical sketch' (1934), in Amanda Sebestyen, ed., Prison letters of Countess Markievicz (London, Virago, 1987), p. 24.

38 Ward, Unmanageable revolutionaries, p. xv.

39 Clarke, Revolutionary woman, p. 170.

40 Rosemary Cullen Owens, Smashing times: a history of the Irish women's suffrage movement 1889-1922 (Dublin, Attic Press, 1984), p. 127.

41 McKillen, 'Irish feminism', p. 56 (July 1912).

42 Ward, Sheehy Skeffington, p. 154.

43 Owens, Smashing times, p. 110.

44 Ward, Sheehy Skeffington, p. 50.

45 Sylvia Walby, Theorizing patriarchy (Oxford, Blackwell, 1990).

46 Ward, Unmanageable revolutionaries, p. 203.

47 Margaret Ward, 'Hannah Sheehy Skeffington (1877-1946)', in Mary Cullen and Maria Luddy, eds, Female activists: Irish women and change, 1900-1960 (Dublin, Woodfield Press, 2001), p. 111.

48 Janet Egleson Dunleavy and Gareth W. Dunleavy, Douglas Hyde: a maker of modern Ireland (Berkeley, University of California Press, 1991), p. 278. 
49 Report of the Gaelic League (Central Branch, Dublin) for two years ending September 30th, 1896 (Dublin, Gaelic League, 1896), pp. 12-13.

50 The name itself was suggested to Arthur Griffith by Máire de Buitleir (Mary Ellen Butler): Máire de Buitleir, "The naming of "Sinn Féin", in Margaret Ward, ed., In their own voice: women and Irish nationalism (Cork, Attic Press, 1995), p. 15.

51 Ruth Taillon, When history was made: the women of 1916 (Belfast, Beyond the Pale, 1996), p. 7.

52 Servant of the queen, p. 294.

53 Owens, Smashing times, p. 112.

54 Servant of the queen, p. 97.

55 Taillon, When history was made.

56 Prison letters of Countess Markievicz, p. 232 (16 July 1919).

57 Clarke, Revolutionary woman, p. 212.

58 Deniz Kandiyoti, 'Identity and its discontents: women and the nation', Millennium: journal of international studies 20 (1991), pp. 429-43.

59 Merritt makes the intriguing case that in constructing the dual identity of Kathleen, Lady Gregory was inviting Yeats to choose older, spiritual, textual Gregory over younger, secular, sexual Gonne. The symbolic woman embodies a private dilemma before it is ever taken up with enthusiasm for its public resonances: Henry Merritt, "Dead many times": Cathleen ni Houlihan, Yeats, two old women and a vampire', Modern language review 96 (2001), pp. 644-53.

60 Gonne-Yeats letters, p. 165 [January 1903].

61 Servant of the queen, p. 64.

62 Okarinen, A dream of liberty, p. 57.

63 Owens, Smashing times, pp. 119-120.

64 Prison letters of Countess Markievicz, p. 229 [5 July 1919].

65 Ibid., pp. 224-5 (21 June 1919).

66 Máire Nic Shiubhlaugh, 'Kathleen Ní Houlihan', in Ward, In their own words, p. 26.

67 R. F. Foster, W. B. Yeats: a life. I. The apprentice mage (Oxford, Oxford University Press, 1997), p. 262.

68 Prison letters of Countess Markievicz, p. 155 (21 Sept. 1916).

69 William Butler Yeats, 'Man and the echo' (1938), in Daniel Albright, ed., W. B. Yeats: the poems (London: Dent, 1990), p. 392; 11 11-12.

70 Fox, Louie Bennett, pp. 120-22.

71 Servant of the queen, p. 9.

72 Ward, Sheeby Skeffington, p. 344.

73 Oikarinen, A dream of liberty, p. 27 (1909).

74 Servant of the queen, p. 366.

75 Lewis, Eva Gore Booth, p. 158.

76 Quoted in McKillen, 'Irish feminism', p. 67 (1915).

77 Gonne-Yeats letters, p. 302 (15 Sept. 1911).

78 Ward, Gonne, p. 22.

79 Eva Gore Booth, 'Roger Casement', in Prison letters of Countess Markievicz, p. 130, 11 7-9.

80 William Butler Yeats, 'Easter 1916' (1916), in Yeats poems, p. 229, 1l. 57-8.

81 Ibid., 11. 41-4.

82 Ibid., p. 230, 11. 75-6

83 Gonne-Yeats letters, p. 384 [8 November 1916]. 
84 Nadje Al-Ali, 'Review article: nationalisms, national identities and nation states: gendered perspectives', Nations and nationalism 6 (2000), pp. 631-8.

85 Iris Dhail Éireann, Official report: debate on the treaty between Great Britain and Ireland signed in London on the 6th December, 1921 (Dublin, talbot Press, 1922), p. 57a.

86 Ibid., p. 91a.

87 Ibid., p. 221b.

88 Ibid., p. $141 \mathrm{~b}$.

89 Ibid., p. 135b.

90 Clarke, Revolutionary woman, p. 192.

91 Debate on the treaty, p. 178b.

92 Ibid., p. 216b.

93 Ward, In their own voice, p. 124.

94 Ibid., p. 125.

95 Debate on the treaty, p. 59b.

96 Ibid., p. $223 \mathrm{a}$.

97 Ibid., p. 250a.

98 Ibid., p. 216b.

99 Ibid.

100 Ibid., p. 304b.

101 Ibid., pp. 216b-217a.

102 Wendy Parkins, 'Protesting like a girl: embodiment, dissent and feminist agency', Feminist theory 1 (2000), pp. 59-78.

103 Marjorie Howes, Yeats's nations: gender, class, and Irishness (Cambridge, Cambridge University Press, 1996), p. 57.

104 Maurice Manning, 'Women in Irish national and local politics, 1922-77', in Margaret MacCurtain and Donncha Ó Carráin, eds, Women in Irish society: the historical dimension (Dublin, Arlen House, 1978), p. 94.

105 Connolly, Irish women's movement, p. 240. Things got somewhat better for women thereafter, and since 1990 Ireland has had a female president, while 20 women were elected to the Dáil in 1992.

106 Ward, In their own voice, p. 134.

107 Ward, Sheehy Skeffington, p. 214.

108 Ward, In their own voice, p. 185.

109 Mary Clancy, 'Aspects of women's contribution to the Oireachtas Debate in the Irish Free State, 1922-37', in Maria Luddy and Cliona Murphy, eds, Women surviving (Dublin, Poolbeg Press, 1989), p. 223.

110 Owens, Smashing times, pp. 130-31.

111 Ward, In their own voice, p. 185.

112 Ibid., p. 187.

113 Ibid., p. 186.

114 Mary Cullen and Maria Luddy, 'Introduction', in Cullen and Luddy, Female activists, p. 7.

115 For a study of the continuing importance of the homosocial world of the prison for Irish republicans, see Lorraine Dowler, "Till death do us part": masculinity, friendship, and nationalism in Belfast, Northern Ireland', Environment and planning D: society and space 19 (2001), pp. 53-71. 